\title{
ODPOWIEDZIALNOŚĆ CZLOWIEKA W ETYCE PRAWA NATURALNEGO
}

\begin{abstract}
Odpowiedzialność jest podstawową kategorią każdej teorii etycznej. Nie jest ona jednak pojmowana tak samo w każdej z tych teorii. Współczesna literatura traktująca o odpowiedzialności dotyczy najczęściej psychologicznego, społecznego, czy prawnego jej aspektu. Brakuje natomiast prac badających sam bytowy fundament odpowiedzialności. Wynika to przeważnie z przyjmowanych w danej teorii etycznej założeń metafizycznych i antropologicznych. Autor niniejszej pracy wchodzi w dyskusję ze współczesnymi ewolucyjnymi i socjobiologicznymi nurtami etyki, które jak twierdzi, spłycają pojmowanie odpowiedzialności pozbawiając ją wymiaru metafizycznego. Bada kategorię odpowiedzialności w etyce prawa naturalnego, bowiem rzeczona teoria etyczna wyróżnia się spośród innych postrzeganiem odpowiedzialność jako struktury bytowej. W pracy podjęto się zadania rekonstrukcji ontycznych podstaw odpowiedzialności w świetle etyki prawa naturalnego. Ukazano, że odpowiedzialność w myśl tej teorii etycznej nie jest ani strukturą ogólnobytową, ani też strukturą rodzajową, to znaczy taką, która byłaby wspólna wszystkim istotom żyjącym i czującym, lecz jest ona zindywidualizowaną strukturą gatunku ludzkiego, poprzez którą spełnia się podmiot moralny jako osoba. W świetle etyki prawa naturalnego odpowiedzialność jest ontyczną strukturą określającą ten wymiar natury ludzkiego bytu, który jest właściwy tyko człowiekowi - osobie. Składowe tej struktury są ze sobą wewnętrznie powiązane i przyporządkowane do ,ja” jako podmiotu moralnego, przez co struktura odpowiedzialności ma charakter analogiczny. Odpowiedzialność jest więc w każdym człowieku zindywidualizowana, to jest częściowo taka sama, a częściowo odmienna. Jest podobna w każdym bytowym przypadku przez to, że jest utworzona z takich samych składowych wewnętrznie ze sobą powiązanych, natomiast strukturę odpowiedzialności częściowo modyfikuje przyporządkowanie jej składowych do niepowtarzalnego osobowego ,ja".
\end{abstract}

Słowa kluczowe: analogia, etyka prawa naturalnego, metafizyka, odpowiedzialność człowieka, ontyczna struktura

\section{WSTĘP}

Zagadnienie odpowiedzialności cieszy się powszechnym zainteresowaniem² ${ }^{2}$ Rozprawiają o niej pedagodzy, filozofowie, etycy etc. Niektórzy w swoich zwięzłych wypowiedziach - kluczach dotykają czegoś ważnego z fenomenu odpowiedzialności. Często powtarzanym jest stwierdzenie Antoine de Saint-Exupery’ego z Małego Księcia, iż pozostajesz na zawsze odpowiedzialny za to, co oswoiłeś, bądź jemu podobną odnoszącą się do sfery ludzkich uczuć wypowiedź kardynała Stefana Wyszyńskiego, iż człowiek jest odpowie-

\footnotetext{
${ }^{1}$ Dr Andrzej Sołtys, Katedra Nauk Humanistycznych, Wydział Zarządzania, Politechnika Rzeszowska im. Ignacego Łukasiewicza, ul. Podkarpacka 1, 35-082 Rzeszów.

${ }^{2}$ Zob. O odpowiedzialności, Znak 1995, nr 10.
} 
dzialny nie tylko za uczucia, które ma dla innych, ale $i$ za te, które u innych budzi, bądź wreszcie znaną myśl Abrahama Lincolna określającą granice odpowiedzialności w podejmowanym działaniu, a mianowicie, że polityk jest odpowiedzialny za statek, nie za fale. Zrelatywizowany współczesny świat potrzebuje jednak nie tyle wiedzy na temat przeżywania poczucia odpowiedzialności, czyli odpowiedzialności związanej z poczuciem winy za zło i związanej z nią sankcji karnej, lecz potrzebuje wiedzy o odpowiedzialności jako strukturze ontycznej, potrzebuje wiedzy o odpowiedzialności wpisanej w naturę osoby ludzkiej, będącej przejawem samego człowieczeństwa ${ }^{3}$.

W niniejszej pracy zbadamy pojęcie odpowiedzialności, jakim operuje etyka prawa naturalnego. Zechcemy odpowiedzieć na pytanie, czym jest odpowiedzialność człowieka w świetle etyki prawa naturalnego. Celem prowadzonej analizy będzie wyodrębnienie koniecznych naturalnych składowych odpowiedzialności z określeniem charakteru ich wzajemnych relacyjnych powiązań. Odsłoni się w ten sposób analogiczny charakter odpowiedzialności, to znaczy jej złożoność z heterogenicznych składowych, pozostających względem siebie $w$ koniecznych relacjach i ontycznie związanych $\mathrm{z}$ dynamicznym podmiotem moralnym jako analogatem głównym. Odpowiedzialność jest przedmiotem filozoficznego poznania. Zasadniczą część poprzedzimy więc ukazaniem tego, jak przyjmowany paradygmat filozofowania modyfikuje postrzeganie fenomenu odpowiedzialności, wskażemy przy tym na paradygmat, w którym uprawia się etykę prawa naturalnego oraz przybliżymy pewne trudności w dochodzeniu do wspólnego tym paradygmatom pojęcia odpowiedzialności.

\section{ODPOWIEDZIALNOŚĆ CZLOWIEKA W POSZCZEGÓLNYCH PARADYGMATACH FILOZOFOWANIA}

Zagadnienie odpowiedzialności przynależy do filozofii człowieka. Filozoficzna interpretacja człowieka implikuje pojęcie odpowiedzialności. Współcześnie wskazuje się na trzy paradygmaty filozoficznego myślenia: starożytny zwany przedmiotowym, bądź ontologicznym, nowożytny nazywany podmiotowym, bądź mentalistycznym i współczesny określany jako dialogiczny bądź lingwistyczny ${ }^{4}$. Każdy z nich ma swój wkład w pojmowanie odpowiedzialności. Filozofowanie w paradygmacie przedmiotowym zmierza do określenia tego, czym jest byt. Konsekwentnie w odniesieniu do odpowiedzialności wysuwa postulat badania odpowiedzialności jako ontycznej struktury. Etyka prawa naturalnego mieści się właśnie w tym paradygmacie filozofowania. Odchodzi ona od traktowania odpowiedzialności jako struktury ogólnobytowej, zrywa także z przekonaniem, iż odpowiedzialność jest fenomenem właściwym istotom żywym ${ }^{5}$, natomiast stoi na stanowisku, że jest ona strukturą ontyczną właściwą wyłącznie istotom rozumnym i wolnym. Jej bytowych racji nie można więc poszukiwać ani w strukturach biologicznych, ani w animalnym psychizmie, jak tylko w tym wymiarze ludzkiego bytu, który odróżnia człowieka od istot żywych i sensytywnych.

\footnotetext{
${ }^{3}$ Por. M. Kunicka, Wychowanie a etyka odpowiedzialności, „Teraźniejszość - Człowiek - Edukacja” 18 (2015) nr 3, s. 61.

${ }^{4}$ Por. H. Schnädelbach, Filozofia [w:] Filozofia. Podstawowe pytania, red. E. Martens, H. Schnädelbach, przeł. K. Krzemieniowa, Warszawa 1995, s. 57-97; J. Filek, Filozofia odpowiedzialności XX wieku, Kraków 2003, s. 5-11; M. Kunicka, Wychowanie..., s. 60.

${ }^{5}$ Nie dokonało się to skokowo, gdyż jeszcze w oświeceniu występowały przypadki pociągania do odpowiedzialności zwierząt. Por. J. Filek, Ontologizacja odpowiedzialności, Kraków 1996, s. 23.
} 
Etyka prawa naturalnego ustawia się więc naprzeciw wszelkim postaciom ewolucyjnej interpretacji genezy fenomenu odpowiedzialności. Nie podziela stanowiska, jakoby socjobiologia udzielała adekwatnych odpowiedzi na pytania dotyczące genezy i funkcji moralności zarówno jednostki jak i społeczeństwa. W przeciwieństwie do tego, co głosi socjobiologia ${ }^{6}$ zwolennicy etyki prawa naturalnego utrzymują, że człowieka nie można zredukować do immanentnego elementu przyrody, którego zachowania moralne i odpowiedzialność jako ich konsekwencja byłyby ukształtowane poprzez dobór naturalny ${ }^{7}$. Uprawianie etyki $\mathrm{w}$ przedmiotowym paradygmacie definitywnie wiąże zagadnienie odpowiedzialności z bytem ludzkim.

W nowożytnym podmiotowym paradygmacie filozofowania człowieka postrzegano jako istotę zdominowaną przez wolę. Zasadniczym filozoficznym pytaniem było dociekanie kim jestem ja-człowiek. Postacią reprezentatywną dla tego paradygmatu filozofowania był I. Kant. W jego filozofii odpowiedzialność ma charakter moralny i jest konsekwencją wyboru przez człowieka maksymy, przez co ten zobowiązuje się do pewnego postępowania, bądź postępowania w pewien sposób. Odpowiedzialność była więc postrzegana jako stan zobowiązania, który spoczywał na woli człowieka w efekcie dokonanego przez nią wyboru maksymy postępowania. Odpowiedzialność w etyce Kanta była w pierwszym rzędzie odpowiedzialnością zasad, wtórnie zaś odpowiedzialnością co do działania. Podmiotowy paradygmat filozofowania jest też określany jako mentalistyczny lub subiektywny. Dobrze to koresponduje $\mathrm{z}$ właściwym dla tego paradygmatu pojęciem odpowiedzialności jako samoodpowiedzialności ${ }^{8}$. Człowiek sam tworzy maksymy dla moralnie dobrego postępowania i odpowiada przed samym sobą. Zbliżoną interpretację odpowiedzialności przedstawił Fryderyk Nietzsche. Jego zdaniem odpowiadanie człowieka przed instancją jest efektem jego słabości i braku umiejętności odpowiadania przed sobą samym. Rzeczywistą odpowiedzialnością człowieka jest według niego odpowiedzialność tylko przed sobą samym ${ }^{9}$. Stanowisko to jeszcze bardziej wyostrzył Jean Paul Sartre. Według niego skazany na absolutną wolność człowiek jest tym samym skazany na absolutną odpowiedzialność za siebie i wobec siebie. Człowiek jest według niego odpowiedzialnym za to, czym jest ${ }^{10}$. Dotychczasowe uzupełnia współczesna dialogiczna interpretacja odpowiedzialności.

Protagonistą dialogicznego (lingwistycznego) paradygmatu filozofowania był Emmanuel Lévinas. W świetle tego paradygmatu odpowiedzialność jest mową. Filozofowanie dialogiczne wychodzi nie od jest (bytu), jak miało to miejsce w paradygmacie przedmiotowym, wychodzi nie od jestem (podmiotu), co jest właściwe dla paradygmatu podmiotowego, lecz wychodzi od jesteś, wychodzi od Ty. Według Lévinasa jesteś apeluje, wzywa mnie do odpowiedzi. Wchodzę więc z Drugim w relacje etyczną ${ }^{11}$. I Ten, któremu odpo-

\footnotetext{
${ }^{6}$ Por. E.O. Wilson, Socjobiologia, przeł. M. Siemiński, Poznań 2000, s. 15; Szeroko na temat ewolucyjnej genezy moralności zob. M. Weiss, Etyka a ewolucja. Metaetyczny kontekst etyki ewolucyjnej, Poznań 2010.

7 Por. H. Mohr, Evolutionäre Ethik als biologische Theorie [w:] Evolutionäre Ethik. Zwischen Naturalismus und Idealismus, red. W. Lütterfelds, Th. Mohr, Darmstadt 1993, s. 19.

${ }^{8}$ Por. B. Niećko-Bukowska, Perspektywy ujęcia odpowiedzialności, „Investigationes Linguisticae” 16 (2008), s. 131.

9 Por. ibidem.

${ }^{10}$ Zob. J.P. Sartre, Byt i nicość: zarys ontologii fenomenologicznej, przeł. J. Kiełbasa i in., Kraków 2007.

${ }^{11}$ Por. M.A. Chojnacka, Problem odpowiedzialności w filozofii Levinasa, „Studia z Historii Filozofii” (2011) nr 2, s. 139.
} 
wiadam jest Tym, za którego odpowiadam. Moje Ja tworzy się poprzez odpowiedź na wezwanie twojego $T y$, twojej inności. W świetle tego paradygmatu być, to tyle, co być zagadniętym, co znajdować się w sytuacji adresata apelu, a nawet zobowiązania do udzielenia odpowiedzi. Definicją człowieka jest więc sama odpowiedzialność, bowiem być podmiotem znaczy wyłącznie być odpowiedzialnym za Drugiego ${ }^{12}$. Odpowiedzialność odkrywa moja ostateczna rzeczywistość ${ }^{13}$. Odpowiedzialność jest więc w tym paradygmacie nie tyle kategorią antropologiczną, co kategorią metafizyczną. Być dla człowieka to tyle, co odpowiadać, ponosić odpowiedzialność za Innego ${ }^{14}$.

Nie istnieje prosta odpowiedź na pytanie, czym jest odpowiedzialność. Badanie odpowiedzialności w poszczególnych paradygmatach filozofowania nie ułatwia zadania wypracowania wspólnego pojęcia odpowiedzialności ${ }^{15}$. Pozostający każdy w swoim paradygmacie filozof, mało konfrontuje swoje pojmowanie odpowiedzialności z pojmowaniem jej przez innych ${ }^{16}$. Każdy paradygmat filozofowania posiada własne metody, własną aparaturę pojęciową i własne schematy pojęciowe, które jako właściwe dla jednego, z wielką trudnością dają się przekładać na schematy pojęciowe należące do innego paradygmatu filozofowania. W konsekwencji nie ma wspólnego pojęcia odpowiedzialności. Niewątpliwie pojmowanie odpowiedzialności w poszczególnych paradygmatach filozofowania przykuwa uwagę do ważnych elementów w tym fenomenie, bądź ważnych jego aspektów, ale trudno wskazać takie pojęcie, które wyjaśniałoby odpowiedzialność całościowo i adekwatnie.

Inna trudność w dochodzeniu do wspólnego pojęcia odpowiedzialności wiąże się z samym sposobem jej poznawania. Pytania o to, czym jest odpowiedzialność nie można umieścić w tym samym szeregu, co inne, spontanicznie wypowiadane pytania jak: czym jest ta rzecz, jak smakuje chleb, dlaczego uważasz, że ten obraz jest piękny. Na te pytania można odpowiedzieć wskazując na rzecz, podając chleb do skosztowania bądź unaoczniając rozmówcy oceniany obraz. W podobny sposób nie odpowiemy na pytanie, czym jest odpowiedzialność człowieka. W przypadku pytań o rzeczy i ich stany możemy uzyskać łatwą odpowiedź, bowiem pytamy o coś, co posiada jakąś naturę, co rządzi się prawami przyrody, czy jednak podobnych odpowiedzi możemy oczekiwać w odniesieniu do odpowiedzialności, skoro jest ona własnością zachowania się istoty moralnej, czyli w swoim działaniu niezdeterminowanej przez prawa przyrody. Ale czy rzeczywiście odpowiedzialność jest tylko własnością ludzkiego działania, czy nie jest raczej tak, że odpowiedzialne działanie jest tylko skutkiem jakiejś bytowej struktury, którą nazwiemy odpowiedzialnością? W konsekwencji,

${ }^{12}$ Substytucja jest najbardziej adekwatnym wyrażeniem odpowiedzialności za Drugiego. Polega ona na wstawianiu się w miejsce Innego. Por. M. Jędraszewski, Wobec Innego. Relacje międzypodmiotowe w filozofii Emmanuela Lévinasa, Poznań 1990, s. 14.

${ }^{13}$ E. Lévinas, Catość i nieskończoność. Esej o zewnętrzności, przeł. J. Migasiński, Warszawa 1998, s. 209.

${ }^{14}$ Por. M.A. Chojnacka, Problem..., s. 142. Można to oddać słowami Antoine de Saint-Exupery'ego, iż być człowiekiem, to wtaśnie być odpowiedzialnym.

15 Jacek Filek próbuje połączyć te trzy paradygmaty filozofowania nadając im pewną ciągłość, co przełożyło by się na jakieś jedno wspólne dla tych trzech paradygmatów filozofowania pojęcie odpowiedzialności. Pisze on: „jeżeli bowiem znam już prawdę, to znaczy, wiem, czym jest prawdziwy byt i prawdziwe bycie, i jeżeli jestem już wolny, to znaczy, należe już do siebie, to wiem też, $\dot{z} e$ tam jesteś ty $i$ że nie mam innego pilniejszego zadania niż o, by $w$ twej biedzie śpieszyć ci z pomoca, choćby mieli mnie wyszydzić czy nawet zabić”. J. Filek, Filozofia odpowiedzialności XX wieku..., s. 7-8.

${ }^{16}$ Por. idem, Ontologizacja odpowiedzialności..., s. 9. 
czy w odpowiedzialności nie należałoby odróżnić poziomu ontycznego (naturalnego) i moralnego. Przyglądnijmy się zatem, w jaki sposób radzi sobie z tymi trudnościami etyka prawa naturalnego.

\section{ANALOGICZNY CHARAKTER ODPOWIEDZIALNOŚCI W ETYCE PRAWA NATURALNEGO}

Odpowiedzialność jest faktem. Wpisana jest bowiem w ludzkie życie. W pierwszym oglądzie jawi się jako struktura relacyjna. Formę tej struktury dobrze opisuje rodzaj odpowiedzialności prawnej, w której jasno się określa: podmiot odpowiedzialności (kto jest odpowiedzialny), przedmiot odpowiedzialności (za co jest odpowiedzialny) i instytucja odpowiedzialności (przed kim jest odpowiedzialny). Takie prawne pojęcie odpowiedzialności, pojmowanej jako pochodna określonego systemu prawnego, może stanowić dobry punkt wyjścia w badaniu istoty odpowiedzialności człowieka, a więc odpowiedzialności ontycznej (naturalnej) ${ }^{17}$ i moralnej. Nie znaczy to jednak, że odpowiedzialność człowieka jest w jakiś sposób zależna od odpowiedzialności prawnej. Zależność jest zgoła odwrotna. Odpowiedzialność prawna jest zależna genetycznie od odpowiedzialności moralnej. Natomiast odpowiedzialność moralna człowieka jest pochodną jego odpowiedzialności ontycznej (naturalnej $)^{18}$. Z tego względu odpowiedzialność moralna, nie będąc pochodną jakiegoś systemu prawnego, a nawet etycznego, jedynie w porządku poznania może zależeć od etyki, ale tylko takiej, która nie tworzy systemu norm, lecz poznając ludzki byt normy takie odczytuje. Taką etyką jest etyka prawa naturalnego. W niej przyjmuje się, iż odpowiedzialność jest wpisana w naturę człowieka i to na jej fundamencie dopiero, urzeczywistnia się odpowiedzialność moralna, będąca konsekwencją aktów decyzyjnych człowieka. Spośród istot żywych tylko człowiek jest podmiotem odpowiedzialności. I jak niezmienną jest jego natura, tak też niezmienną pozostaje jego odpowiedzialność będąca składową tej natury. Odpowiedzialność moralna w etyce prawa naturalnego nie jest wiec obciążona relatywizmem, lecz wynika z systemu niezmiennych norm naturalnych, które Stwórca wpisał w sumienie każdego człowieka ${ }^{19}$.

$\mathrm{Z}$ takim pojęciem odpowiedzialności wiążą się jednak pewne trudności. Etyka prawa naturalnego musi przyjąć, iż istnieje pewna stała natura człowieka i że zawiera ona w sobie moment normatywny ${ }^{20}$. Problematyzowanie istnienia natury ludzkiej podważa, iż człowiek posiada jakieś wewnętrzne i niezmienne cele. Współcześni krytycy prawa naturalnego opierają swoje twierdzenia na przekonaniu, że jeśli nawet przypiszemy człowiekowi naturę, to i tak ma ona charakter wtórny względem społeczeństwa, tworzonej przez niego kultury, bądź nawet takich naturalnych procesów rzeczywistości jak proces ewolucji. Naturalistycznie nastawiony Petrinovich twierdzi, iż wszystko, co jest w naturze człowieka pochodzi z biologii i środowiska, bądź wpływu czynników socjo-kulturowych ${ }^{21}$. Następstwem tego

${ }^{17} \mathrm{Na}$ temat ontycznych podstaw odpowiedzialności w fenomenologicznym nurcie filozofowania zob. R. Ingarden, Ksiażeczka o człowieku, Kraków 1987, s. 39-156.

${ }^{18}$ Szeroko na temat naturalnego wymiaru odpowiedzialności człowieka zob. R.J. Kruszyński, Odpowiedzialność naturalna człowieka, „Acta Universitatis Lodziensis Folia Iuridica” 74 (2015), s. 9-19.

${ }^{19}$ Por. Jan Paweł II, Dziesięcioro przykazań, Kraków 2012, s. 37.

${ }^{20}$ Por. J. Herbut, Prawo naturalne [w:] Leksykon filozofii klasycznej, red. J. Herbut, Lublin 1997, s. 444.

${ }^{21}$ Por. L. Petrinovich, Human Evolution, Reproduction, and Morality, London 1998, s. 107. 
poglądu jest odrzucenie przekonania, że natura ludzka zawiera w sobie moment normatywny i że ten jest pierwotnym źródłem zobowiązań moralnych. Pogląd ten ostatecznie podważa istnienie niezmiennej odpowiedzialności moralnej, implikowanej przez ludzką naturę. Naturalistyczna interpretacja natury ludzkiej przekształca system normatywny, osadzony na tej naturze oraz związaną z nim odpowiedzialność, w relatywizm etyczny. Są jednak mocne racje podważające ten tok myślenia.

$\mathrm{W}$ polemice $\mathrm{z}$ relatywizmem etycznym możemy odwołać się do doświadczenia moralnego. Na tej drodze podważa relatywizm etyczny Grzegorz Hołub ${ }^{22}$. Zwraca uwagę, że różne kultury i religie proponują odmienne przekonania na temat aksjologicznej wartości tych samych ludzkich działań. Jesteśmy zamknięci w kontekstach kulturowych i przejmujemy od nich fundamentalne przekonania moralne. Chociaż przekonania te są rozbieżne, to jednak ich różnorodność nie musi koniecznie prowadzić do postawy relatywistycznej. Spierając się z innymi o to, co jest w danej sytuacji słuszne nie podważamy tym samym, że to, co słuszne istnieje $\mathrm{e}^{23}$. Hołub zauważa, że zróżnicowane przekonania etyczne mają pewne wspólne elementy jak choćby przekonanie, że istnieje doświadczenie moralne. Spieramy się o kształt jakiegoś konkretnego rozwiązania etycznego, jednak spór taki zakłada zgodność na wcześniejszym, bardziej podstawowym poziomie naszego doświadczenia i wie$\mathrm{dzy}^{24}$. I to ten właśnie poziom jest naturalnym źródłem, z którego wypływa powinność moralna i związana $\mathrm{z}$ nią odpowiedzialność. Jeśliby nie było tego podstawowego poziomu, wówczas nie dysponowalibyśmy żadnym kryterium do formułowania oceny i wypowiadania etycznego sądu. Na tym właśnie fundamencie nabudowuje się powszechne przekonanie, że trzeba pewne czynności spełniać, gdyż są one dobre, natomiast innych unikać, bo są złe i z tego samego gruntu wyrasta również odpowiedzialność podmiotu moralnego ${ }^{25}$. Jakie zatem składowe tworzą naturalną strukturę odpowiedzialności człowieka?

Znaczący wkład w wyjaśnienie tego zagadnienia mają prace Karola Wojtyły ${ }^{26}$. Ten jako personalista pozostaje w głównym nurcie etyki prawa naturalnego. Wojtyła zwraca uwagę, że rozważania dotyczące odpowiedzialności często koncentrują się na jej wymiarze społecznym, międzyludzkim. Tymczasem zdaniem tego filozofa odpowiedzialność jest najpierw rzeczywistością w osobie, wewnątrz osoby i to ona jest dopiero podstawą odpowiedzialności społecznej ${ }^{27}$. Odpowiedzialność jako rzeczywistość wewnątrzosobowa ma pewną naturalną bytową strukturę, która z kolei ujawnia się w osobowym działaniu człowieka. Według Wojtyły nie ma innego wglądu w tę strukturę, jak tylko poprzez analizę ludzkiego działania.

Spontanicznie wiążemy odpowiedzialność ze sprawczością. Mówimy, że człowiek jest odpowiedzialny za $x$, bowiem jest sprawcą $x$ - $a^{28}$. Tymczasem odpowiedzialność bardziej określa osobę, aniżeli spełniany przez nią czyn. Czyn bowiem jest tylko wewnętrznym skutkiem ontycznej odpowiedzialności człowieka i jako taki jest on składową odpowiedzialno-

\footnotetext{
22 Por. G. Hołub, Etyka prawa naturalnego i etyka medyczna a kategoryczność nakazu moralnego [w:] Oblicza natury ludzkiej, red. P. Duchliński, G. Hołub, Kraków 2010, s. 443.

${ }^{23}$ Por. R. Speamann, Granice. O etycznym wymiarze dziatania, przeł. J. Merecki, Warszawa 2006, s. 17.

24 Por. G. Hołub, Etyka prawa..., s. 443.

${ }^{25}$ Por. M.A. Krąpiec, Ludzka wolność i jej granice, Warszawa 1997, s. 234-235.

${ }^{26}$ Chodzi tu głównie o dwie prace K. Wojtyły: Osoba i czyn oraz Miłość i odpowiedzialność.

27 Por. Jan Paweł II, Osoba i czyn, Warszawa 2008, s. 237.

${ }^{28}$ Por. ibidem.
} 
ści moralnej. Oczywiście czyn może także powodować skutek zewnętrzny, lecz ten nie współtworzy odpowiedzialności moralnej. Według Wojtyły ontyczna (naturalna) odpowiedzialność jest racją odpowiedzialności moralnej. Odpowiedzialność ontyczna jest substrukturą bytu ludzkiego utworzoną z woli, jej intencjonalności i powinności. Wyodrębnione teoretycznie składowe są bardziej rozpoznawalne w analizie wykształcania się czynu.

Wola odznacza się podwójną intencjonalnością. Jest ona bowiem z jednej strony naturalnie zwrócona ku analogicznie pojętemu dobru, z drugiej strony jest odniesiona do ja podmiotu moralnego, który jako pierwszy adresat czynu jest uprzedmiotowiony w działaniu $^{29}$. Wola jest nakierowana na swój przedmiot właściwy, którym jest analogicznie pojęte dobro $^{30}$. Analogicznym dobrem jest wielość jednostkowych i konkretnych bytów. Realnie istniejące byty są zamienne $\mathrm{z}$ dobrem, co św. Tomasz wyraził formułą bonum et ens convertuntur $^{31}$. Z racji naturalnego nakierowania woli na analogiczne dobro wola może się spełniać w swej naturze. Analogiczne dobro nie jest pełnią dobra, lecz jest mnogością dóbr cząstkowych zróżnicowanych ilościowo i jakościowo, stąd żadne dobro nie ukoniecznia woli w jej wyborze. Z kolei naturalne skierowanie woli na ja przejawia się w tym, że ja rozpoznaje prawdę o przedmiocie czynu, którym jest dobro pozostające w pierwszym rzędzie w relacji do dobra osoby ludzkiej - podmiotu czynu, wtórnie zaś do innych dóbr. Intencjonalność przedmiotowa woli oraz przedstawiona jej przez ja prawda o dobru, którym jest przedmiot czynu, rodzi w ja powinność i tworzy tym samym właściwe warunki dla ukonstytuowania się aktu rozumnego - czynu ${ }^{32}$.

Aktem rozumnym jest takie działanie ja - podmiotu moralnego, które pochodzi sprawczo od jego woli, zdeterminowanej do działania przez rozumowe poznanie dobra (celu) ${ }^{33}$. Z kolei rozumność aktu warunkuje jego poczytalność, to znaczy jego sprawczą przynależność do podmiotu. Poczytalność jest stanem ciągłości podmiotu moralnego. Podmiot jest świadomy tego, że konkretny czyn jest czynem słusznym, bądź niesłusznym, czynem dobrym, bądź złym oraz że powodowany przez niego czyn przynależy do niego jako jego sprawcy, niezależnie od tego, czy podmiot sprawiający ten czyn zewnętrznie się do niego przyznaje, czy też nie. I dopiero poczytalność czynu rodzi szczególny jego związek z podmiotem moralnym - osobą, zwany odpowiedzialnością moralną ${ }^{34}$. Rozumność aktu oraz poczytalność są to więc konieczne warunki dla ukonstytuowania się odpowiedzialności moralnej człowieka. Odpowiedzialność moralna jest więc taką właściwością podmiotu, na mocy której wartość moralna, spełnianego przez ten podmiot czynu, staje się składową moralnej treści jego osobowości, czego skutkiem jest ponoszenie przez ten podmiot, związanych z czynem konsekwencji ${ }^{35}$. Przedstawiony proces rodzenia się czynu i związanej z nim odpowiedzialności moralnej podmiotu pomógł wyodrębnić istotne składowe ontycznej struktury odpowiedzialności, czyniącej z człowieka istotę odpowiedzialną na mocy jego osobowej natury.

\footnotetext{
${ }^{29}$ Por. ibidem, s. 240.

${ }^{30}$ Szerzej na temat analogicznego charakteru dobra zob. A. Sołtys, Różne oblicza dobra [w:] Etyka i dobro, red. D. Probucka, Kraków 2015, s. 136-139.

31 Tomasz z Akwinu, In Sententiarum II, d. 34, q. 1, a. 2.

32 Por. Jan Paweł II, Osoba..., s. 239.

33 Por. T. Ślipko, Zarys etyki ogólnej, Kraków 1984, s. 50.

34 Por. ibidem, s. 385.

${ }^{35}$ Por. ibidem, s. 386.
} 
Konstytuuje ją układ powiązanych ze sobą i wzajemnie zależnych od siebie składowych. Żadnej z nich nie można rozpatrywać samej w sobie, lecz w sieci koniecznych relacji. Wojtyła wskazuje na wolę, powinność, sprawczość oraz podmiotowe następstwa sprawczości, jako naturalne składowe struktury odpowiedzialności. Są one wzajemnie powiązane relacjami aspektowych zależności i każda z nich jest przyporządkowana do tego samego podmiotu moralnego. Dwie pierwsze tworzą analogiczną bytową strukturę odpowiedzialności, na której dopiero poprzez czyn wykształca się odpowiedzialność moralna podmiotu. Zdaniem Wojtyły odpowiedzialność, jakkolwiek ujawnia się wraz z powinnością, to jednak w porządku realnym uprzedza ukonkretnioną powinność, gdyż jest u początku jej zaistnienia. $Z$ tego wynika, iż powinność wchodzi w strukturę odpowiedzialności jako potencjalny stan woli, którym jest konieczna relacja woli do analogicznie pojętego dobra. Wyraża się ona ogólnym zobowiązaniem, iż dobro należy czynić, a zła unikać (bonum est faciendum et prosequendum, et malum vitandum $)^{36}$. Uprzednia w stosunku do powinności odpowiedzialność ustawia powinność działania, w istotnej dla podmiotu moralnego perspektywie następstw tego działania, jako zgodnego, bądź niezgodnego z powinnością.

Struktura utworzona z czynu i jego następstw, powiązanych ze sobą relacją przyczynowo - skutkową, konstytuują odpowiedzialność moralną człowieka. Jest ona również strukturą wewnątrzosobową, bowiem chodzi o czyn pojmowany jako akt podmiotu moralnego - osoby oraz powodowane przez niego następstwa w nim samym jako bycie osobowym. Odpowiedzialność moralna jest w swej istocie odpowiedzialnością podmiotu moralnego za siebie samego, który w spełnianym przez siebie czynie przenosi wartość dobra przedmiotowego na siebie samego. Struktura odpowiedzialności moralnej umożliwia więc przepływ moralnego dobra, to znaczy dobra wybieranego przez podmiot moralny, ze sfery obiektywnego porządku moralnego w duchowe wnętrze działającej osoby. Przeżycie odpowiedzialności przez podmiot moralny kształtuje ostatecznie moralną osobowość człowieka $^{37}$. Odpowiedzialność za wartość moralną przedmiotu czynu jest w gruncie rzeczy odpowiedzialnością za wartość moralną podmiotu - sprawcę czynu, czyli odpowiedzialnością za siebie samego ${ }^{38}$. Właśnie taka zintegrowana postać odpowiedzialności za jest według Wojtyły istotnie tym, co nazywamy odpowiedzialnością moralną ${ }^{39}$. W etyce prawa naturalnego odpowiedzialność jest jak widać wewnątrzosobową strukturą umożliwiającą realizowanie się osobowego ja poprzez czyn. Odpowiedzialność umożliwia samostanowienie się osoby w czynie. Odpowiedzialność moralna powoduje, że dobroć czynu integralnie wiąże się z jego sprawcą, o ile ten jest podmiotem moralnym. Wartość moralna czynu staje się wartością moralną osoby spełniającej ten czyn.

\section{ZAKOŃCZENIE}

Odpowiedzialność w etyce prawa naturalnego ma charakter analogiczny. Tworzy ją bowiem układ powiązanych ze sobą, koniecznych i dynamicznych relacji, przebiegających między wolą i jej intencjonalnością, czynem i jego następstwami dla podmiotu. Odpowie-

\footnotetext{
36 Tomasz z Akwinu, Summa theologiae, I-II, q. 94, a. 2. Komentarz tego tekstu źródłowego zob. M. Piechowiak, Filozofia praw człowieka, Lublin 1999, s. 298-299; M.A. Krąpiec, Człowiek i prawo naturalne, Lublin 1993, s. 202 i n.

${ }^{37}$ Por. T. Ślipko, Zarys..., s. 386.

${ }^{38}$ Zob. K. Wojtyła, Miłość i odpowiedzialność, red. T. Styczeń i in., Lublin 1986, s. 23-30.

${ }^{39}$ Por. Jan Paweł II, Osoba..., s. 240.
} 
dzialność, jako analogiczny system relacji powiązanych ze sobą realnymi odmianami wzajemnych zależności, tworzących analogiczną jedność poprzez odniesienie każdej z nich do tego samego podmiotu moralnego, wiąże ze sobą w sposób konieczny nie tylko części z całością, ale także całość, którym jest podmiot moralny z całym światem osób ${ }^{40}$. Układ wewnętrznych w stosunku do podmiotu moralnego składowych odpowiedzialności, powiązanych ze sobą różnymi relacjami, tworzących jedność poprzez stosunek do tego samego ja oraz stosunek ja do innych osób stanowi dopiero pełny wymiar analogicznego charakteru odpowiedzialności człowieka, odpowiedzialności ontycznej (naturalnej) i moralnej. Analogiczny charakter odpowiedzialności powoduje, iż odpowiedzialność jako struktura ontyczna choć jest powszechna, to jednak w każdym bytowym przypadku częściowo jest odmienna, stąd też i odpowiedzialność moralna realizuje się w każdym człowieku w nieco odmienny indywidualny sposób.

\section{LITERATURA}

[1] Chojnacka M.A., Problem odpowiedzialności w filozofii Levinasa, ,Studia z Historii Filozofii" (2011) nr 2, s. 133-147.

[2] Filek J., Filozofia odpowiedzialności XX wieku, Wydawnictwo Znak, Kraków 2003.

[3] Filek J., Ontologizacja odpowiedzialności, Baran i Suszczyński, Kraków 1996.

[4] Herbut J., Prawo naturalne [w:] Leksykon filozofii klasycznej, red. J. Herbut, TN KUL, Lublin 1997.

[5] Hołub G., Etyka prawa naturalnego i etyka medyczna a kategoryczność nakazu moralnego [w:] Oblicza natury ludzkiej, red. P. Duchliński, G. Hołub, Wydawnictwo WAM, Kraków 2010.

[6] Ingarden R., Książeczka o człowieku, Wydawnictwo Literackie, Kraków 1987.

[7] Jan Paweł II, Dziesięcioro przykazań, Wydawnictwo M, Kraków 2012.

[8] Jan Paweł II, Osoba i czyn, KAI, Warszawa 2008.

[9] Jędraszewski M., Wobec Innego. Relacje międzypodmiotowe w filozofii Emmanuela Lévinasa, Księgarnia św. Wojciecha, Poznań 1990.

[10] Krąpiec M.A., Człowiek i prawo naturalne, RW KUL, Lublin 1993.

[11] Krąpiec M.A., Ludzka wolność i jej granice, Wydawnictwo Gutenberg-Print, Warszawa 1997.

[12] Kruszyński R.J., Odpowiedzialność naturalna człowieka, „Acta Universitatis Lodziensis Folia Iuridica" 74 (2015), s. 9-19.

[13] Kunicka M., Wychowanie a etyka odpowiedzialności, „Teraźniejszość - Człowiek - Edukacja” 18 (2015) nr 3, s. 59-70.

[14] Lévinas E., Całość i nieskończoność. Esej o zewnętrzności, przeł. J. Migasiński, Wydawnictwo Naukowe PWN, Warszawa 1998.

[15] Mohr H., Evolutionäre Ethik als biologische Theorie [w:] Evolutionäre Ethik. Zwischen Naturalismus und Idealismus, red. W. Lütterfelds, Th. Mohr, Darmstadt 1993.

[16] Niećko-Bukowska B., Perspektywy ujęcia odpowiedzialności, „Investigationes Linguisticae" 16 (2008), s. 130-139.

[17] Petrinovich L., Human Evolution, Reproduction, and Morality, The MIT Press, Cambridge - London 1998.

${ }^{40}$ Por. ibidem, s. 241. 
[18] Piechowiak M., Filozofia praw człowieka, TN KUL, Lublin 1999.

[19] Sartre J.P., Byt i nicość: zarys ontologii fenomenologicznej, przeł. J. Kiełbasa i inni, Wydawnictwo Zielona Sowa, Kraków 2007.

[20] Schnädelbach H., Filozofia [w:] Filozofia. Podstawowe pytania, red. E. Martens, H. Schnädelbach, przeł. K. Krzemieniowa, Wiedza Powszechna, Warszawa 1995.

[21] Sołtys A., Różne oblicza dobra [w:] Etyka i dobro, red. D. Probucka, Wydawnictwo Naukowe Uniwersytetu Pedagogicznego, Kraków 2015.

[22] Speamann R., Granice. O etycznym wymiarze działania, przeł. J. Merecki, Oficyna Naukowa, Warszawa 2006.

[23] Ślipko T., Zarys etyki ogólnej, Wydawnictwo WAM, Kraków 1984.

[24] Tomasz z Akwinu, In Sententiarum II, d. 34, q. 1, a. 2.

[25] Tomasz z Akwinu, Summa theologiae, I-II, q. 94, a. 2.

[26] Weiss M., Etyka a ewolucja. Metaetyczny kontekst etyki ewolucyjnej, Wydawnictwo Poznańskie, Poznań 2010.

[27] Wilson E.O., Socjobiologia, przeł. M. Siemiński, Zysk i S-ka, Poznań 2000.

[28] Wojtyła K., Miłość i odpowiedzialność, red. T. Styczeń i in., TN KUL, Lublin 1986.

\section{THE RESPONSIBILITY OF MAN IN THE ETHICS OF NATURAL LAW}

Responsibility is the basic category of every ethical theory; however, the human responsibility is not understood in the same way in every ethical theory. Contemporary literature concerning the problem of responsibility of man examines first of all the psychological, social and legal aspect of responsibility. There are few works that relate to the ontological aspect of responsibility. The reason for such a situation in the ethical theories are mostly the metaphysical and anthropological assumptions. The author of present article does not agree with the contemporary trends of evolutionary and sociobiological ethics, and affirms that these trends simplify the concept of responsibility of a man and deprive its metaphysical dimension. The author examines the concept of human responsibility in the ethics of natural law because the ethics of natural law stands out from other ethical theories and it sees responsibility as the structure of being. The article reconstructs the ontological basis of human responsibility in the light of the ethics of natural law. It has been shown that the responsibility according to that ethical theory is neither a common structure for all beings, nor a generic structure i.e. a common structure of every living and feeling beings, but it is an individualized structure of the human species, through which the moral subject i.e. the person realizes itself. In view of the natural law ethics, responsibility is the ontological structure typical of man - person only. The elements constituting the structure of responsibility are connected to each other internally and are assigned to the entity, in this way, the structure of human responsibility is analogous, this means that the responsibility of man is in every human being individualized.

Keywords: analogy, natural law ethics, metaphysics, responsibility of man, ontological structure.

DOI: $10.7862 /$ rz.2017.hss.57

Przestano do redakcji: luty 2017 r.

Przyjęto do druku: wrzesień 2017 r. 